"This is the peer reviewed version of the following article: [Asian Economic Journal, 2015, 29 (1), pp. 41 - 60 (11)], which has been published in final form at [http://dx.doi.org/10.1111/asej.12046]. This article may be used for non-commercial purposes in accordance with Wiley Terms and Conditions for SelfArchiving." 


\title{
The Long Run Effect of the Global Financial Crisis on Singapore's Tourism and the Economy
}

\begin{abstract}
The short-run effect of the 2008 Global Financial Crisis upon tourism and-the economy of Singapore and tourism in particular has been well observed, but the magnitude of long-rung effect is still not clear. This study employs recent Singaporean tourism survey data, the updated Singaporean input-output tables, and a Computable General Equilibrium (CGE) model to gauge the long-run effects of the 2008 Global Financial Crisis and selected policy responses. The simulation results suggest that the global financial crisis has had mild negative long-run effects on the overall development of Singapore's economy, and that the GST deduction policy ought to offset this negative effect.
\end{abstract}

Keywords: CGE Modelling, financial crisis, policy response, Singaporean economy

\section{Introduction}

Singapore’s economy has historically beenrelied heavily reliant upon its 'entrepot' status because of limited natural resources yet advantageous geographical position. Due to the efforts of Singapore’s government aimed at diversifying its economy, the Singapore of today can be described as having a 'two-pillar' economy, with the manufacturing and service industries contributing most to overall prosperity. Within the service industry, the tourism sector plays a key role. In 2007, the Singapore tourism sector set a record of 10.3 million visitor arrivals (STB, 2009) and generated US\$9.4 billion in tourism receipts, accounting for 3\% of Singapore's GDP (RNCOS, 2009). According to Euromonitor (2007), Singapore is the world's fourth-most visited city in terms of visitor arrivals and the third most preferred convention city destination in terms of the number of meetings held in 2006. Nevertheless, the importance of tourism in the economy has declined over time, as shown in Figure 1. 
Figure 1 the shares of tourism receipts from 1991 to 2011

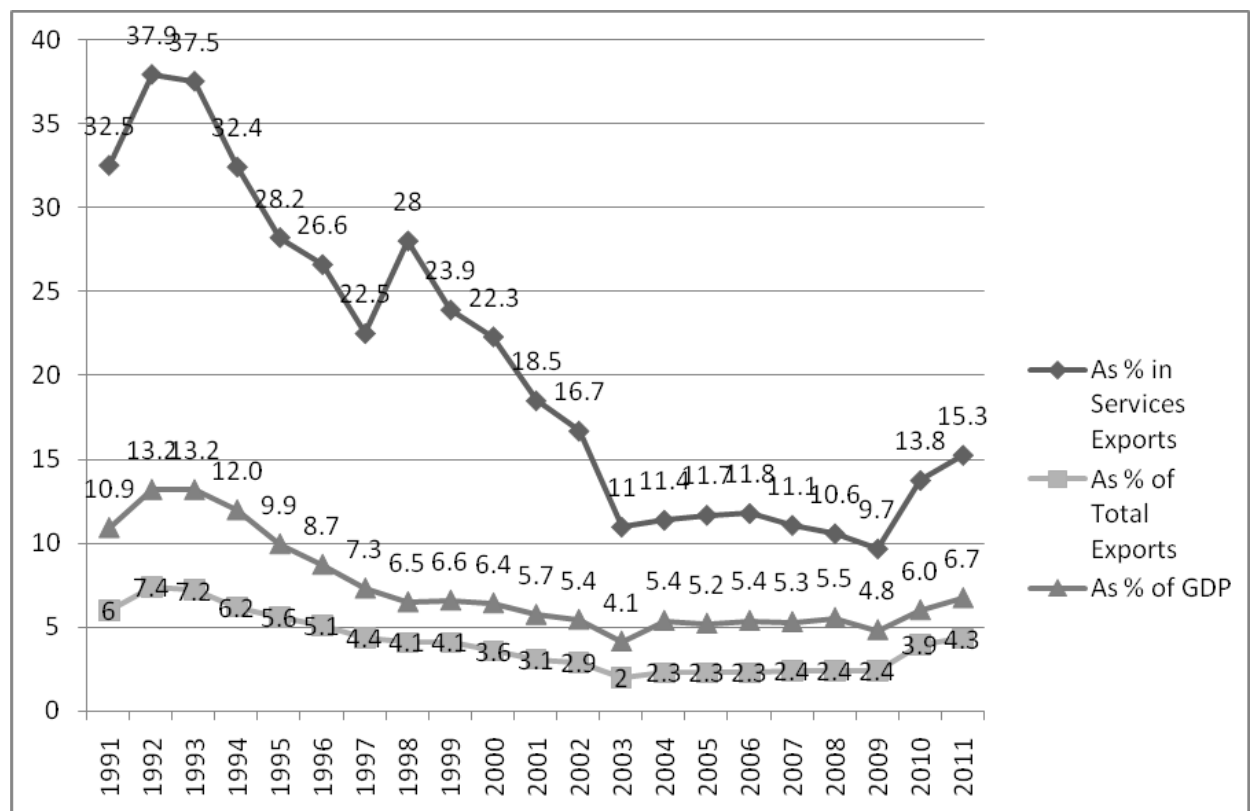

Source: based on Annual report on Tourism statistics, STB (2000 to 2012).

Figure 1 depicts the relative share of tourism receipts in services exports, total services and goods exports, and GDP in recent years. The overall portrait provided is that the share of tourism receipts declined consistently and considerably during 1992-2003. Following this, the decline was much smaller and stabilized. Given the increasing trend of tourism receipts shown in Figure 1, the sharper decline of the share in services exports in Figure 1 indicates the tremendous increase in services exports, especially in trade, financial services and business services. These services accounted for more than $41 \%$ of total value-added activity in the service industry in 2007 (MTI, 2008). The low shares in total exports demonstrate the large volume of merchandise trade in Singapore. The declining pace of tourism shares in total exports was slower than that of tourism shares in service exports because merchandise exports increased steadily but not as rapidly as services exports. The share of tourism receipts in GDP dropped from 13.2\% in 1992 to $4.1 \%$ in 2003 . This decline indicates, on the one hand, the markedly increased value-added economic activity in the nontourism sectors and on the other hand, the small size and lack of tourism resources in Singapore, which constrains the ability to attract more tourism dollars. However, the shares of tourism receipts 
in GDP nevertheless stabilized at around 5.0\% from 2004 to 2009. They grew substantially from 2009 onwards. From Figure 1 it is reasonable to conclude that, although inbound tourism has recently played a less important role in the Singaporean economy, its contribution to the economy is still very significant.

Thanks to its openness and small size, the Singapore economy was severely affected by the 2008 Global Financial Crisis. In particular, its tourism industry was hit hard. According to STB (2009), Singapore inbound-tourism receipts declined by $13.5 \%$ in the first half of 2009 compared with the first half of 2008. In terms of GDP, the Singapore economy contracted by 2.0 per cent in 2009 (MTI, 2009). Although this short-run impact of the global financial crisis is in this sense obvious, its long run effect is unknown. By employing the latest Singaporean tourism survey data and updated input-output tables, and by constructing a Computable General Equilibrium (CGE) model for the Singapore economy, this study gauges the long run effects of the Global Financial Crisis and canvasses different policy options on Singapore's tourism and the economy more generally.

The paper consists of five main parts. Section 2 provides a brief review of previous studies. Section 3 describes the model structure, database and simulation designs. Section 4 discusses the simulation results. The paper concludes in section 5 with some general observations on prospects for the future of Singapore's tourism industry.

\section{Previous studies}

Despite the rapid growth of the Singaporean tourism industry and its significant effect upon the economy, research examining the economic impact of tourism in Singapore has been limited. Moreover, previous studies (see, for example, Diamond, 1979; Seow, 1981; Heng and Low, 1990; Khan et al., 1990) have suffered from some limitations. First, the data are 20 to 30 years old and therefore cannot reveal the role of tourism in the modern Singaporean economy. Second, the methodology used, namely input-output (I-O) modelling, is problematic. More recent studies have 
unanimously agreed that input-output modelling has serious limitations (see, for example, Briassoulis, 1991; Johnson, 1999; and Blake, 2000). Since there is a large body of literature on the application of CGE modelling to tourism, for the purpose of this study, only those examining the effects of negative mega events upon tourism and the economy are reviewed.

Adams, et al. (2002) estimated the impact of the September 11 terrorist attacks on tourism forin Australia and on-the Australian economy. They used a Monash dynamic CGE model to generate macro and sectoral base-case forecasts on pre-September 11 assumptions and an alternate simulation including the downturn caused by the 9-11 events. Through the comparison of the basecase forecast and the alternate simulation, the study claimed that the 9-11 event would result in a sharp downturn in the international tourism industry, which would have negative impacts on real GDP, aggregate consumption and aggregate imports, and would reduce Australia's terms of trade and causes serious adverse effects on employment in some heavily tourist-dependent regions and sub-regions. However, the model showed that the overall reductions in employment wouldill be not much more than 10 per cent.

Blake, et al. (2003) used a CGE model to analyse the impacts of Foot and Mouth Disease (FMD) on tourism and the UK economy. First, a micro-regional tourism simulation model was employed to estimate the reduction of tourism expenditures due to FMD. The model estimated a fall of almost $£ 7.5$ billion in total tourism revenue in 2001. A CGE model was then used to estimate the economic impact of a tourism contraction. The results indicated that the economic impact of a tourism contraction would be much bigger than the effect of a reduction in affected agricultural products. The total fall in GDP due to the FMD crisis was estimated at $£ 2.5$ billion pounds, of which the fall in GDP as a result of tourism expenditure reduction accounted for $£ 1.93$ billion. Moreover, the model suggested that FMD would negatively affect tourism and the economy for several years.

Narayan (2003) applied a CGE model to estimate the long--term economic impacts of the military coup in Fiji in May-2000. The study used post-coup statistical data as the basis for modelling. For example, following the insurgence, visitor arrivals fell by $39.4 \%$, investment fell by 
33.1\%, private transfers aboard increased by $\mathrm{F} \$ 36.6$ million, government expenditure increased by 9.9\% and the real interest rate increased by $3.5 \%$. Since the focus of the study concerned the long run effects, the CGE model assumed that capital was mobile across the sectors and that the capital stock was adjusted to a fixed rate of return to capital. The main findings of the model were that real GDP fell by around $8.2 \%$, exports declined by around $14.9 \%$, the BOP deficit increased by $\mathrm{F} \$ 4.8$ million and government revenue fell by around $4.8 \%$. At the sector level, the real outputs of the hotel, transportation, commerce, and business services industries were among the most affected, largely due to the sharp fall in visitor arrivals.

Many researchers have used ether-methods other than CGE to study the effect of the Global Financial Crisis on Asia. Using an autoregressive distributed lag model (ADLM), Chon et al. (2010) estimated the recovery of tourism demand in Hong Kong from the Global financial Crisis. Although the tourism demand dropped by $8.9 \%$ in the 2009Q2, their estimation indicated that tourism demand in Hong Kong is relatively resilient to the GFC. Chan (2011) constructed a financial engineering model to assess the impact of the GFC on Macao's gross entertainment revenue. The results suggested that Macao's tourism industry is closely correlated with the performance of the global financial markets. Chirathivat and Mallikamas (2010) examinedeoneened Thailand's economic performance and responses to the GFC. They pointed out the large negative impact of the GFC on Thai GDP and exports (2.3\% and 12.7\% decrease in 2009, respectively) and concluded that the expansionary fiscal and monetary policies in Thailand were quite effective. Shankaran (2009) investigated the impact of both the Asian Financial Crisis and the Global Financial Crisis on Malaysia. The paper concluded that Malaysia is particularly vulnerable to a global crisis because of its strong dependence on exports, of which tourism is an important part. The paper also suggested a rebalancing strategy as the response to the GFC. Rodolfo (2009) studied the impact of the GFC on Philippine tourism. The study highlighted the impact of the GFC on inbound tourism (35\%-50\% decline in bookings in 2009) and suggested the ways to boom tourism in Philippines including 
government stimulus package, strong private sector participation, cost reduction in tourism industry and diversification of tourism source markets.

\section{A CGE model for Singapore tourism and the economy}

This study employs a computable general equilibrium approach. Compared with other methodologiesy such as partial equilibrium studies and input-output modelling, the main advantage of CGE modelling is that it can take into account the intersectoral linkages as well as the feedback effect in the economy. However,, but the drawback is that CGE modelling required extensive data and an extensivelarge amount of time to build a model. The model developed for this study is a static CGE model based on ORANI G (Horridge 2000) and belongs to the Johansen class of CGE models. The TABLO language was used to build the model and GEMPACK 10 was used to implement the simulations.

\subsection{Model assumptions and structure}

The model employed neoclassical economic assumptions: a perfectly competitive economy with constant returns to scale; cost minimisation for industries and utility maximisation for households; continuous market clearance; perfectly mobile labour across industries, while capital was treated as industry-specific. Zero profit conditions were assumed for all industries because of perfect competition in the economy. Since Singapore is a small open economy, it was assumed that it is a price-taker in the world market.

The Singapore economy was represented by 34 industries producing 34 goods and services, one representative investor, one household sector, one government and eight occupation groups. Tourism shopping and non-shopping demands were extracted from exports as independent final demands for the purpose of the study. The production function was a 4-level nested CET-LeontiefCES function: the top level was a Constant Elasticity of Transformation (CET) function allowing for firms to change products with some flexibility; the second level was a Leontief function reflecting fixed proportions among the composite intermediate inputs and composite primary 
factors; the third level was a Constant Elasticity of Substitution (CES) function reflecting the substitution effect between import and domestic inputs and between labour and capital; and the bottom level was a CES function reflecting the substitution effect among different labour groups. The household demand function was a 2-level nested LES-CES function. The LES function at the top reflected the ability of households to adjust their combination of consumption in response to income changes. The CES function at the bottom reflected the flexible choice between imported and domestic goods in household consumption. The tourism non-shopping demand was a 2-level nested Leontief-CES function and the tourism shopping demand was a 2-level nested Cobb-Douglas and CES function.

\subsection{Data and parameters}

Data needed for this study are mainly input-output data and tourism expenditure data. The input-output data were readily available from the 2005 Singapore I-O tables. These data were adjusted for use in this CGE model. Firstly, the data were updated to a base year of 2006 by employing the RAS method. Secondly, the 152 industries and commodities in the Singapore inputoutput table were aggregated to fit the purpose of the study.

We chose 2006 as the base year of our simulation because the purpose of the study was to assess the impact of the GFC through a representative shock of GFC (13.5\% drop in inbound tourism demand). As such, the base year should be prior to 2008 when the GFC happened. While 2007 would be the obvious choice, it is widely believed that the symptoms of the GFC had already appeared in 2007, so 2006 was assessed as a representative normal economic period prior to the GFC. The input-output tables were not available for 2006 but were available for 2005, so we updated them to 2006 using the RAS method. The advantage of RAS method is minimum change in the ratios in the original I-O table (2005 in this case) while the totals (of production, consumption, taxes) will be consistent with the new base year (2006 in this case). Since industrial, structural and technological change (represented by the ratios in the I-O tables) was negligible from 2005 and 
2006, the RAS method ${ }^{1}$ was assessed as most suitable for this study. The tourism expenditure data were taken from the 2006 Singapore tourism survey (STB, 2007). Since shopping expenditure comprises the bulk of total tourism spending, we disaggregated the data according to the tourism shopping pattern in the Singapore tourism survey. Since the data for modelling is for 2006, the modelling results may become indicative when they are interpreted against the current situation of Singapore's tourism and the economy.

The behavioural parameters in this study mainly consisted of import-domestic substitution elasticities, factor substitution elasticities, product transformation elasticities, consumer demand elasticities and export demand elasticities. The Armington elasticities, factor substitution elasticities, household demand elasticity and expenditure elasticity were adopted from the GTAP 6 database. Following Siriwardana and Schulze (2000), the elasticities of substitution between different labourer types were assigned a value of 0.5 for every industry. There were no econometric estimates for product transformation elasticities for Singapore. However, estimates of CRETH transformation parameters in the ORANI model for the Australian economy have values between 0.06 and 4.55, with most of the estimates around 0.3-0.5 and 1.3-1.6 in value. Taking into account the size and structure of the Singapore economy, we adopted 0.4 as an estimate for the agriculture sector in Singapore and 1.5 for other sectors.

As a small country, Singapore has a small share in world markets, so its production could not affect world prices. In other words, its export supply is very elastic. As such, a value of -20.0 was assigned to the foreign demand elasticity for Singapore's non-manufactured exports. In the case of manufactured goods, Singapore has a huge capacity in the production of oil products, non-metal chemical products and electronic goods. Hence, values of -5.5 were assigned to those sectors and 10.0 for the other manufacturing sectors.

These elasticity values were based on the best information available and upon the authors'

\footnotetext{
${ }^{1}$ The RAS method was formally developed by Richard Stone et al (1962) and it can be traced back to Richard Stone et al (1942). Parikh (1979) provided the details about how to use the RAS method to update input-output tables. This method repeatedly scales up/down a matrix to satisfy the new column total and the row total until the new matrix sums up to the new column total and row total, so this method has minimum impact on ratios in the matrix.
} 
judgement using economic theory and economic reasoning, so it is invalid to claim that they are accurate or 'true' for the Singapore economy. To be sure of the simulation results, we performed sensitivity tests on these elasticities.

\subsection{Model closure and simulation scenarios}

Since the total number of variables in the model was more than the number of equations, some variables needed to be set as exogenous. For the purpose of this study, the following variables were specified as exogenous for all simulations: technical changes, consumer taste changes, tax rates, CPI, government spending, tourism demand, and inventory. Since full employment is achievable through the adjustment of flexible real wages in the long run, this study considered aggregate employment as exogenous.

According to the STB, Singaporean tourism receipts in the first half of 2009 were estimated at S\$6.4 billion, a decline of 13.5 per cent compared with the first half of 2008. Consequently, a 13.5\% negative shock to Singapore tourism demand was chosen for the baseline case. The policy options considered in this study were based on previous studies and different approaches of policies adopted. For a demand-side approach, although the tool of tourism tax has been suggested by some researcherssome researchers have suggested the tool of a tourism tax, it is not practical since it is very hard to differentiate tourists from local people in purchasing (sellers do not check the national identity of buyers). Thus, for a consumer side policy, this study excluded this option and only considered a broader sales tax deduction: a $1 \%$ decrease in the power of $\mathrm{GST}^{2}$. For a supply approach, two options were considered. One was a $1 \%$ subsidy ( $1 \%$ decrease in production tax rate) to all producers, which is also a broad policy alternative to GST deduction. The other was a $4 \%$ subsidy to tourism industries, which represented the tourism-focused approach. The subsidy rate to tourism industries was chosen so that the total loss of tax revenue for this policy would be similar to that in the $1 \%$ economy-wide subsidy policy. Thus, the following four scenarios were simulated.

\footnotetext{
${ }^{2}$ The power of GST means one plus GST rate. For a $10 \%$ GST rate, the power of GST is 1.10 . A $1 \%$ increase in the power of GST means that it decreases by $1.1-1.1 * 1 \%=1.089$, so the GST rate becomes $8.9 \%$ which is $1.1 \%$ decrease from the original rate. In other words, given $10 \%$ GST rate, $1 \%$ decrease in the power of GST is equivalent to $1.1 \%$ decrease in GST rate.
} 
Scenario (I): $13.5 \%$ decrease in total tourism expenditure in the long run;

Scenario (II): Scenario I plus 1\% decrease in the power of GST;

Scenario (III): Scenario I plus 1\% subsidy to all industries;

Scenario (IV): Scenario I plus 4\% subsidy to tourism industries.

It was expected that the results for Scenario (I) would be negative and significant given the large size of the shock. The negative impact on tourism sectors would be substantial given that the shock originated from tourism demand. The GST reduction policy in scenario (II) and the indiscriminate subsidy policy in Scenario (III) were expected to have significant positive effects on the economy, but the relative effectiveness would be an unknown, due to complex interactions upon both the demand and supply sides. The tourism subsidy policy in Scenario (IV) was expected to have a substantial positive impact on tourism related industries while the impact on the whole economy was expected to be milder because the tourism industry only accounts a small part of the economic activity in Singapore.

\section{Simulation results}

The above four scenarios were simulated using a CGE model and GEMPACK version 10 software. The simulation results are shown in Tables 1 to 4 . With a few exceptions, values in the tables are shown as percentage changes compared with the baseline case. Because the results may be sensitive to parameter specification, so sensitivity tests were performed for each simulation. The testing results are provided at the end of this section.

\subsection{Macroeconomic effect}

Table 1 displays the projected macroeconomic effects of all simulation scenarios. From Table 1 we can grasp the main features of the macroeconomic effects of a $13.5 \%$ negative tourism demand shock, with and without policy responses. First, tax revenue and household welfare changes (the first four rows) were different for each simulation scenario. Without a policy response, total tax revenue (tariff, indirect tax and production tax) decreased by less than S\$19 million, the bulk of 
which was derived from the decrease in indirect tax revenue. The GST deduction policy response would lead to a decrease of $\mathbf{\$} \$ 5.6$ billion in indirect tax revenue. Other tax revenue (tariff and production tax) actually increased by a small amount. The $1 \%$ indiscriminate industrial subsidy resulted in not only a loss of $\mathrm{S} \$ 4$ billion production tax, but also an approximate $\mathrm{S} \$ 4$ billion loss of indirect tax revenue. Although tariff revenue increased slightly, the total tax revenue loss amounted to almost $\mathrm{S} \$ 8$ billion. The $4 \%$ subsidy to the tourism industry led to negative growth in all three parts of tax revenue. The total loss was around $\mathrm{S} \$ 6$ billion, similar to that under the GST policy. The welfare change was measured by equivalent variation (EV), namely the change in utility measured in dollar value, or the amount of income at the initial price level needed to achieve the new level of utility. The $13.5 \%$ decrease in inbound tourism had a mild negative impact on household welfare - only a decrease of $\mathbf{S} \$ 1.439$ million shown in scenario 1 . This mild effect was expected because the inbound tourism affected international trade significantly but affected household consumption only mildly. The decrease in the GST rate increased household welfare substantially - by S\$35.969 million. There may be two reasons for this. One is that a reduction in tax reduces the distortion in the economy and thus increases the efficiency. The other is that the demand side approach allowed household to change their consumption bundles so as to maximise utility. For the two policies of supply side approach, the tourism-focused subsidy resulted in a much higher welfare increase. This may have been because of the high intensity of unskilled workers in the tourism industry. Unskilled workers are usually low income earners. Under the tourism-focused subsidy policy these workers would have more income and thus a higher level of consumption. An increase in consumption by the poorer generally can achieve higher social welfare than the same amount of increase in consumption by a wealthier cohort.

Second, the effects on prices are shown in the second panel. The GDP deflator decreased in all cases except scenario (IV). The deflation after the negative tourism demand shock is easily understood by the contraction of final demand (the opposite side of demand-pull inflation). The accelerated deflation under the GST policy is explained by increased efficiency due to the decreased 
tax distortion to the economy (specifically, a sales tax deduction would reduce the tax payment burden, not only upon consumers but also on producers). The discriminate subsidy policy decreased domestic prices by reducing production costs. However, under the tourism subsidy policy, the price level increased. This unusual change can be understood when we check the prices for a different part of final demand (we have listed investment price and tourism shopping and service prices as an example). The negative tourism demand shock led to the decrease of most prices (e.g. most of the tourism shopping and service prices), but the price index for investment goods increased, which indicates that firms increased investment in the face of the negative final demand shock. It is of interest to note the significantly larger increase of investment price index in scenario (IV), which implies that a large amount of the subsidy to the tourism industry would be transformed into investment in the industry. This significant increase in investment demand bid up the investment price which in turn dragged up the GDP deflator in scenario (IV).

Third, nominal GDP decreased in the first three scenarios, but increased under the tourism subsidy policy. This GDP change was significantly influenced by the change of price level. As shown in real GDP, the GST reduction policy and the indiscriminate subsidy policy actually reversed the negative effect under scenario (I). Surprisingly, the tourism subsidy policy slightly worsened economic growth in the long run. The negative effect of a tourism subsidy policy may have resulted from inefficient resource allocation induced by this policy: the discriminate subsidy made the tourism industry appear more profitable and thus attract capital and labour from other industries. Thus, the output of the tourism industry increases, but this increase was not enough to compensate the contraction of other industries. As a result, total output fell further compared to that without policy response.

All policy responses brought about positive effects on payment to primary factors. Without a policy response, payment to labour decreased but the payment to capital increased marginally, so the overall effect on payment to primary factors was negative. The GST policy increased the payment to primary factors to the greatest extent but it also had some pro-capital flavour. The 
overall effects of both subsidy policies on the payment to primary factors was quite similar (around a $2.50 \%$ increase), but the indiscriminate subsidy policy was in favour of capital while the tourism focused subsidy policy increased the payment to labour much more.

Table 1 Macroeconomic effects of a negative tourism demand shock and policy responses

\begin{tabular}{|c|c|c|c|c|}
\hline Macros & $\begin{array}{l}\text { 13.5\% decrease in total } \\
\text { tourism expenditure in } \\
\text { the long run } \\
\text { (I) }\end{array}$ & $\begin{array}{l}\text { Scenario (I) plus } \\
\text { 1\% decrease in } \\
\text { the power of GST } \\
\text { (II) }\end{array}$ & $\begin{array}{l}\text { Scenario (I) plus } \\
1 \% \text { subsidy to } \\
\text { all industries } \\
\text { (III) }\end{array}$ & $\begin{array}{l}\text { Scenario (I) plus } \\
4 \% \text { subsidy to } \\
\text { tourism industry } \\
\text { (IV) }\end{array}$ \\
\hline Tariff revenue* & -2.468 & 18.978 & 5.286 & -9.186 \\
\hline Indirect tax* & -10.215 & -5650.076 & -3961.768 & -2933.851 \\
\hline Production tax* & -6.281 & 51.889 & -4038.952 & -2997.362 \\
\hline $\mathbf{E V}^{*}$ & -1.439 & 35.969 & 8.461 & 23.587 \\
\hline GDP deflator & -0.029 & -0.213 & -0.124 & 0.341 \\
\hline investment price index & 0.064 & 0.147 & 0.197 & 0.714 \\
\hline Tourism shopping price & -0.173 & -0.483 & -0.475 & -0.988 \\
\hline Tourism service price & -0.236 & 0.162 & -0.221 & -2.714 \\
\hline Exchange rate & 0.137 & 0.147 & -0.01 & 0.061 \\
\hline Real devaluation & 0.166 & 0.361 & 0.115 & -0.279 \\
\hline Terms of trade & -0.046 & -0.238 & -0.125 & 0.055 \\
\hline Nominal GDP & -0.077 & -0.182 & -0.119 & 0.285 \\
\hline Real GDP & -0.048 & 0.032 & 0.005 & -0.056 \\
\hline Capital rental & 0.026 & 4.099 & 2.816 & 1.946 \\
\hline Wage & -0.1 & 3.413 & 2.425 & 2.904 \\
\hline Factor cost index & -0.034 & 3.772 & 2.63 & 2.403 \\
\hline Nominal imports & 0.082 & 2.14 & 0.82 & -0.572 \\
\hline Real imports & -0.055 & 1.991 & 0.829 & -0.632 \\
\hline Nominal exports & 0.734 & 1.772 & 0.893 & -0.029 \\
\hline Real exports & 0.642 & 1.865 & 1.028 & -0.144 \\
\hline $\begin{array}{l}\text { BOT contribution to } \\
\text { GDP (real)* }\end{array}$ & 0.858 & 0.078 & 0.344 & 0.529 \\
\hline BOT/GDP (nominal)* & 0.008 & -0.002 & 0.002 & 0.006 \\
\hline
\end{tabular}

*Absolute change: Singapore dollars (million).

Finally, international trade increased in all policy options except in scenario (IV), as shown in the last panel in Table 1. The positive, real devaluation of the Singapore dollar in scenarios (I) to (III) made domestic goods cheaper compared with those in world market, so it is understandable that, without a policy response, Singapore's real imports decreased and real exports increased. The other reason for the increase in real exports is the decrease in tourism shopping expenditure. Tourists tend to buy products in Singapore and take them home. These products would otherwise be part of exports. In scenario (II) and (III), the real devaluation had a similar effect, but the positive 
effects of an increase in real GDP on international trade dominated, so we see both imports and exports increase. In scenario (IV), the increase in domestic price level would have encouraged imports and discouraged exports, but due to the overwhelming negative effect of the decrease in real GDP on imports, both imports and exports decreased.

Overall, GST policy encouraged international trade best, followed by the indiscriminate subsidy policy. However, if we check the contribution of balance of trade (BOT) to GDP, we find the worst numbers in scenario (II) and (III) both in nominal and real terms. The low contribution of BOT to GDP is explained by the fact that the GDP grew faster than international trade.

\subsection{Sectoral effect}

There were 34 sectors in the model, but for simplicity only twenty-two sectors were selected, half of which were tourism related. Also for simplicity, we only display the output and the gross rate of return on capital for each sector in Table 2, although there are many variables describing the sectoral effects.

Examining the sectoral output, in scenario (I),-it is clear that the tourism related sectors (i.e. the first eleven rows in Table 2) were generally hit much harder than the other sectors. This result is explained by the source of the shock. However, the specific effects on sectors, both within and outside the tourism industry, were different. In the tourism industry, Accommodation, Clothing and Drink \& Tobacco were hit hardest. This output fell by $11.09 \%, 7.03 \%$ and 3.50\% respectively. Sightseeing, Food \& Beverage (F\&B) and Health Care were also affected adversely and significantly, whereas the other sectors were affected very mildly. Interestingly enough, the output of the Trade sector increased by $0.50 \%$. The reason for this may be that tourism shopping consists of only a very small proportion of total trade service and exports increase considerably. For the nontourism sectors, most showed a positive growth in output. Although forecast growth was very mild for most of them, Storage Service and Other Manufacture increased output by $1.03 \%$ and $1.10 \%$, respectively. This may suggest that these sectors are tourism-competing industries. A few sectors were affected negatively but very mildly, such as the Electronics, Utilities, Finance, and Real Estate 
sectors; but the Precise Engineering sector was hit fairly hard - 1.78\% decrease in its output. This result may suggest that Precise Engineering is closely linked to the tourism sector. For example, some high--value souvenirs may come from this industry.

Table 2 Sectoral output and gross rate of return on capital

\begin{tabular}{|c|c|c|c|c|c|c|c|c|}
\hline \multirow[t]{2}{*}{ Sector } & \multicolumn{2}{|c|}{$\begin{array}{l}\text { 13.5\% decrease in total } \\
\text { tourism expenditure in } \\
\text { the long run (I) }\end{array}$} & \multicolumn{2}{|c|}{$\begin{array}{l}\text { Scenario (I) plus 1\% } \\
\text { decrease in the } \\
\text { power of GST (II) }\end{array}$} & \multicolumn{2}{|c|}{$\begin{array}{l}\text { Scenario (I) plus 1\% } \\
\text { subsidy to All } \\
\text { industry (III) }\end{array}$} & \multicolumn{2}{|c|}{$\begin{array}{l}\text { Scenario (I) plus 4\% } \\
\text { subsidy to tourism } \\
\text { industry (IV) }\end{array}$} \\
\hline & Output & $\begin{array}{c}\text { Gross rate } \\
\text { of return } \\
\text { on capital }\end{array}$ & Output & $\begin{array}{c}\text { Gross rate } \\
\text { of return } \\
\text { on capital }\end{array}$ & Output & $\begin{array}{c}\text { Gross rate } \\
\text { of return } \\
\text { on capital }\end{array}$ & Output & $\begin{array}{c}\text { Gross rate } \\
\text { of return } \\
\text { on capital }\end{array}$ \\
\hline Food Manufacture* & -0.927 & -1.257 & 4.126 & 8.228 & 2.585 & 5.337 & 24.285 & 31.831 \\
\hline Drink \& Tobacco* & -3.504 & -6.697 & -4.15 & -4.648 & -3.645 & -4.695 & -2.465 & -2.504 \\
\hline Clothing* & -7.03 & -8.846 & -5.658 & -3.902 & -5.893 & -5.197 & 2.615 & 5.5 \\
\hline Wood \& Print* & -0.911 & -1.437 & -1.339 & 1.372 & -0.85 & 1.02 & 3.726 & 7.518 \\
\hline Trade* & 0.497 & 0.408 & -1.551 & 1.422 & -0.726 & 1.371 & 3.239 & 5.971 \\
\hline F \& B* & -2.291 & -2.104 & -2.487 & 0.949 & -2.33 & 0.174 & -0.954 & 1.264 \\
\hline Accommodation* & -11.087 & -7.134 & -11.004 & -3.923 & -11.018 & -4.857 & -10.832 & -4.808 \\
\hline Local transport* & -0.818 & -1.366 & -1.366 & 1.061 & -1.108 & 0.526 & 1.215 & 3.927 \\
\hline Sightseeing* & -2.438 & -2.763 & -2.662 & 0.288 & -2.578 & -0.594 & -2.482 & -0.554 \\
\hline Health care* & -1.237 & -1.299 & -1.652 & 1.734 & -1.405 & 0.916 & 1.302 & 3.412 \\
\hline Recreation* & -0.011 & -0.156 & -0.247 & 2.681 & -0.013 & 2.149 & 1.883 & 4.166 \\
\hline Oil manufacture & 0.044 & -0.024 & 5.223 & 18.661 & 2.663 & 9.984 & -0.888 & -0.519 \\
\hline Electronics & 0.044 & -0.034 & 1.951 & 9.334 & 0.99 & 5.259 & -1.182 & -1.387 \\
\hline Precise engineering & -1.781 & -3.631 & -4.005 & -4.673 & -2.916 & -3.535 & -0.552 & 1.103 \\
\hline Other manufacture & 1.102 & 1.83 & -1.5 & 0.511 & -0.169 & 1.918 & 1.085 & 4.195 \\
\hline Utility & -0.07 & -0.44 & -0.146 & 2.16 & 0.048 & 2.347 & -0.355 & 0.305 \\
\hline Storage service & 1.026 & 0.658 & -1.743 & 1.797 & -0.523 & 1.791 & 2.044 & 3.825 \\
\hline Communication & 0.109 & 0.189 & -0.347 & 2.126 & -0.172 & 1.66 & -0.864 & -0.647 \\
\hline IT & 0.515 & 0.326 & 5.254 & 8.445 & 2.997 & 5.147 & -5.932 & -3.597 \\
\hline Finance & 0.114 & 0.04 & -1 & 1.434 & -0.512 & 1.287 & 0.997 & 4.032 \\
\hline Real estate & -0.011 & -0.212 & -0.211 & 2.382 & -0.126 & 1.697 & -0.36 & 0.672 \\
\hline Other business service & 0.324 & 0.392 & -0.801 & 1.844 & -0.234 & 1.814 & -0.27 & 1.7 \\
\hline
\end{tabular}

*tourism related sectors

Under scenario (II), several sectors showed a significant increase in output. Food Manufacture in the tourism industry, for example, expanded production by $4.13 \%$. In the non-tourism industry, the IT sector increased its output by as much as 5.25\%; Oil Manufacture and Electronics sectors expanded their output by $5.22 \%$ and $1.95 \%$, respectively. All the other sectors experienced negative growth. Surprisingly, they reduced output further compared with the baseline case, except Accommodation and Clothing. These different growth rates may be explained by the difference in volume of output of each sector. Due to the ad valorem nature of GST, sectors with a high volume of output, like Oil Manufacturing and IT, would benefit more from the GST deduction. The 
advantage these sectors have is that they attract resources from other sectors. As a result, they expanded at the expense of the others.

The output in scenario (III) tells a similar but much milder story. Five sectors expanded their output and all the others were placed in recession, but changes in output were much smaller compared with those in scenario (II). For instance, the IT and Food Manufacture sectors grew at $3.00 \%$ and $2.59 \%$ respectively, instead of $5.25 \%$ and $4.13 \%$ as under the GST policy. Compared with the baseline case, three tourism sectors - Clothing, Wood and Print, and Accommodation improved slightly; but the others face a situation worse than in scenario (I) but better than under the GST deduction policy.

Scenario (IV) showed a substantial improvement in all tourism sectors. While most tourism sectors expanded their output in the range from 1.22\% to 3.73\%, the Food Manufacture sector was the biggest winner, increasing its output by $24.29 \%$. However, Sightseeing, F \& B, Accommodation, and Drink and Tobacco were placed in recession - with the Accommodation sector experiencing an 11.02\% decrease in output. The sluggishness of these core tourism sectors manifest in the vitality of tourism demand for them. Although no subsidies were paid to non-tourism sectors in the model, three of them experienced significant growth; Storage Service grew by 2.04\%, Other Manufacture by $1.09 \%$, and Finance by $1.00 \%$. However, the other non-tourism sectors retreated. Although most retractions were mild, the IT sector shrank by as much as 5.93\%.

The rate of return on capital indicates the profitability of sectors. Table 2 demonstrates that the profitability of a sector is related to, but not determined by, the changes in output. When output experiences a large change (e.g., Drink and Tobacco, Clothing and Accommodation in all scenarios; Food Manufacture and IT under all policy responses; and Oil manufacture in scenario (II) and (III)), the behaviour of the rate of return on capital follows that of output. But when the change in output is not large (e.g. many cases in scenario (II) and (III)), not all changes in the return to capital are in the same direction as that of corresponding output. Interestingly, in scenario (I), when the output in Oil Manufacture and Electronics increased slightly, the rate of return on capital decreased 
marginally; but in other scenarios, while output experiences significant contraction (e.g. Trade and F\&B in scenario (II) and (III) and Precise Engineering in scenario (IV)), the rates of return on capital were significantly positive.

The opposite movement of output and the rate of return on capital in scenario (I) may have derived from the behaviour of firms under recessionary conditions. In order to avoid the costs of change (such as compensation packages for fired workers, idleness of machinery, loss of skilled workers, etc.), firms tend to keep output growing at the expense of a temporary loss in profit. The different behaviour of output and the rate of return on capital in scenario (II), (III) and (IV), may reflect the influence of proposed polices on firms' profitability. As the firm's output decreases, the utilization of its fixed capital decreases. Thus the return on capital is likely to drop. However, as discussed earlier, both the GST deduction policy and subsidy policies will lead to lower commodity prices and thus higher demand for commodities. This increased demand will result in an increase in demand for primary factors. As the aggregate capital is fixed in the model (capital constraint), the capital rental price has to rise. Thus, the return on capital increases. When the decrease of output is not large, the positive policy effect overpowers the negative effect of decreased utilization of fixed capital, and the return on capital remains positive.

\subsection{Wage Effect}

Since nominal wages are fully indexed with CPI and CPI is unchanged under the assumption of flexible exchange (the change of price level is expressed as a change in exchange rate), the changes in nominal wage and real wage were the same. Thus, it is not necessary to differentiate real wage and nominal wage in our simulation. We start with sectoral average wage. Because real wage, by definition, is a marginal product of labour whichlabour that directly affects output, we list the output when tabulating average wage by sector, as shown in Table 3

One feature of the projection reported in Table 3 is that average wage followed corresponding output quite closely. The change in wage and output are always in the same direction, with no exception; and the magnitude of change in wage, to some degree, is the magnified change in output. 
This strong link is explained by the constraint of labour supply in our simulation assumption. In the long run, the economy is assumed to operate under full employment (or at a natural rate of unemployment). Assuming an unchanged population in Singapore, total employment is fixed. With the rigid labour supply, the change in output had to be the result of the increased productivity of labour, so the output and wage would go hand in hand.

Table 3 Average wage by sector

\begin{tabular}{|c|c|c|c|c|c|c|c|c|}
\hline \multirow[t]{2}{*}{ Sector } & \multicolumn{2}{|c|}{$\begin{array}{l}\text { 13.5\% decrease in total } \\
\text { tourism expenditure in } \\
\text { the long run } \\
\text { (I) }\end{array}$} & \multicolumn{2}{|c|}{$\begin{array}{c}\text { Scenario (I) plus } \\
\text { 1\% decrease in } \\
\text { the power of GST } \\
\text { (II) }\end{array}$} & \multicolumn{2}{|c|}{$\begin{array}{c}\text { Scenario (I) plus } \\
\text { 1\% subsidy to All } \\
\text { industry } \\
\text { (III) }\end{array}$} & \multicolumn{2}{|c|}{$\begin{array}{l}\text { Scenario (I) plus } \\
4 \% \text { subsidy to } \\
\text { tourism industry } \\
\text { (IV) }\end{array}$} \\
\hline & Output & Real wage & Output & Real wage & Output & Real wage & Output & Real wage \\
\hline Food Manufacture* & -0.927 & -1.23 & 4.126 & 5.506 & 2.585 & 3.443 & 24.285 & 33.126 \\
\hline Drink \& Tobacco* & -3.504 & -7.299 & -4.15 & -8.621 & -3.645 & -7.589 & -2.465 & -5.159 \\
\hline Clothing* & -7.03 & -10.845 & -5.658 & -8.752 & -5.893 & -9.111 & 2.615 & 4.108 \\
\hline Wood \& Print* & -0.911 & -1.601 & -1.339 & -2.349 & -0.85 & -1.494 & 3.726 & 6.621 \\
\hline Trade* & 0.497 & 0.964 & -1.551 & -2.995 & -0.726 & -1.405 & 3.239 & 6.325 \\
\hline F \& B* & -2.291 & -3.262 & -2.487 & -3.541 & -2.33 & -3.318 & -0.954 & -1.361 \\
\hline Accommodation* & -11.087 & -11.497 & -11.004 & -11.411 & -11.018 & -11.425 & -10.832 & -11.233 \\
\hline Local transport* & -0.818 & -2.029 & -1.366 & -3.381 & -1.108 & -2.746 & 1.215 & 3.037 \\
\hline Sightseeing* & -2.438 & -3.274 & -2.662 & -3.574 & -2.578 & -3.461 & -2.482 & -3.332 \\
\hline Health care* & -1.237 & -1.428 & -1.652 & -1.905 & -1.405 & -1.621 & 1.302 & 1.504 \\
\hline Recreation* & -0.011 & -0.016 & -0.247 & -0.353 & -0.013 & -0.018 & 1.883 & 2.705 \\
\hline Oil manufacture & 0.044 & 0.157 & 5.223 & 19.507 & 2.663 & 9.739 & -0.888 & -3.153 \\
\hline Electronics & 0.044 & 0.166 & 1.951 & 7.478 & 0.99 & 3.763 & -1.182 & -4.404 \\
\hline Precise engineering & -1.781 & -4.354 & -4.005 & -9.684 & -2.916 & -7.088 & -0.552 & -1.358 \\
\hline Other manufacture & 1.102 & 2.525 & -1.5 & -3.399 & -0.169 & -0.385 & 1.085 & 2.485 \\
\hline Utility & -0.07 & -0.387 & -0.146 & -0.809 & 0.048 & 0.265 & -0.355 & -1.964 \\
\hline Storage service & 1.026 & 1.383 & -1.743 & -2.346 & -0.523 & -0.704 & 2.044 & 2.76 \\
\hline Communication & 0.109 & 0.447 & -0.347 & -1.412 & -0.172 & -0.702 & -0.864 & -3.497 \\
\hline IT & 0.515 & 0.621 & 5.254 & 6.355 & 2.997 & 3.62 & -5.932 & -7.121 \\
\hline Finance & 0.114 & 0.259 & -1 & -2.268 & -0.512 & -1.165 & 0.997 & 2.281 \\
\hline Real estate & -0.011 & -0.058 & -0.211 & -1.104 & -0.126 & -0.657 & -0.36 & -1.876 \\
\hline Other business service & 0.324 & 0.701 & -0.801 & -1.728 & -0.234 & -0.506 & -0.27 & -0.585 \\
\hline
\end{tabular}

The other feature of Table 3 is that different policy responses had different effects on sectoral wages. The GST policy greatly increased the average wage in four sectors: $19.51 \%$ increase in Oil Manufacture, 5.51\% in Food Manufacture, 7.48\% in Electronics and 6.36\% in IT sector. But other sectors are rendered in recession. The indiscriminate subsidy policy affected sectoral wage in a way similar to GST policy. But this policy, with much more government spending (or tax revenue loss), increased wages much less than the GST policy. The tourism subsidy policy made an impressive improvement in the tourism sectors; e.g.: 33.13\% increase in Food Manufacture, 6.33\% in the Trade sector, 6.62\% in Wood \& Print and 3.04\% in Local Transport. Some non-tourism sectors also made

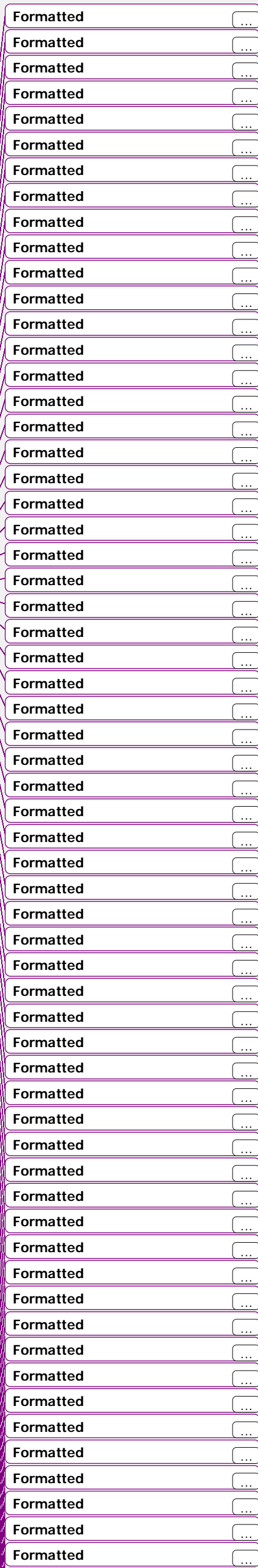


significant improvements, e.g.: 2.49\% in Other Manufacture, 2.76\% in Storage Service, and 2.28\%

in Finance. However, even with this tourism-focused policy, some tourism sectors such as the F\& B, Accommodation, Sightseeing and Drink \& Tobacco, are still in contraction. The explanations of policy effect on output - the nature of policies and the free intersectoral movement of capital in the long run - are equally applicable here.

The average wage by occupation group reveals another facet of the labour market, as shown in Table 4.

Table 4 Average wage by occupation group

\begin{tabular}{|c|c|c|c|c|c|}
\hline Occupation group & $\begin{array}{l}\text { 13.5\% decrease in total } \\
\text { tourism expenditure in } \\
\text { the long run } \\
\text { (I) }\end{array}$ & $\begin{array}{l}\text { Scenario (I) plus } \\
\text { 1\% decrease in } \\
\text { the power of GST } \\
\text { (II) }\end{array}$ & $\begin{array}{l}\text { Scenario (I) plus } \\
1 \% \text { subsidy to } \\
\text { All industry } \\
\text { (III) }\end{array}$ & $\begin{array}{l}\text { Scenario (I) plus } \\
4 \% \text { subsidy to } \\
\text { tourism industry } \\
\text { (IV) }\end{array}$ & Formatted: Font color: Auto \\
\hline Managers & 0.191 & -0.092 & 0.021 & 0.65 & Formatted: Font color: Auto \\
\hline Professionals & 0.083 & 0.301 & 0.237 & -0.541 & Formatted: Font color: Auto \\
\hline Technicians & 0.074 & -0.075 & -0.001 & -0.247 & Formatted: Font color: Auto \\
\hline Tradesmen & 0.052 & -0.389 & -0.221 & 0.155 & Formatted: Font color: Auto \\
\hline Clerks & -0.803 & -2.279 & -1.702 & 1.319 & Formatted: Font color: Auto \\
\hline Sales men & -0.097 & 2.674 & 1.563 & -0.751 & Formatted: Font color: Auto \\
\hline Plant workers & 0.015 & 1.182 & 0.62 & -1.559 & Formatted: Font color: Auto \\
\hline Other Labourers & -1.132 & -1.054 & -1.068 & -0.835 & Formatted: Font color: Auto \\
\hline
\end{tabular}

In scenario (I), it is apparent that the skilled occupation groups (the first 4 rows) were better positioned in the wake of the negative tourism demand shock, while unskilled workers experienced wage decline or a marginal wage increase, the average wage for skilled workers increased significantly. These results can be explained as follows. Since the tourism industry has a high share of unskilled workers (e.g. clerks and other labourers), a decrease in tourism demand will lead to a decrease in demand for these unskilled workers and thus their wages will decrease significantly. The decrease in tourism demand will also lead to lower price levels for the economy, which will stimulate demand for non-tourism goods and thus lead to an increase in the demand for workers in non-tourism industries. The net effect of this is an increase in wages for skilled workers because of the high share of skilled workers in non-tourism industries and because the wages of unskilled workers are predominantly affected by the negative tourism demand shock. The milder increase of 
wages for plant workers may be due to the fact that manufacturing industries (e.g. food manufacturing and precise engineering) are loosely related to the tourism industry through tourism shopping. The demand for plant workers is negatively but mildly affected by a decrease in tourism demand while positively affected by an increase in demand for non-tourism goods. As a result, the wages for plant workers increase marginally.

The wage changes in other scenarios were more complex. In scenario (II) and (III), Salesmen benefited most: a $2.67 \%$ average wage increase in scenario (II) and 1.56\% increase in scenario (III). Plant Workers arrive as the second group of beneficiaries. The luck of these two groups is apparently brought about by the increase in output of some manufacture sectors under the GST or discriminate subsidy policies. The other two unskilled occupations were worst affected: the wages for Clerks and Other Labours declined by around $2.00 \%$ and $1.00 \%$ respectively. In the skilled occupation groups, the Professionals experienced a significant wage increase, but Tradesmen have to accept small wage cuts. The wage changes in the two other groups are not significant. These results can be explained as follows: the GST reduction policy leads to significant decrease in price level (i.e. $-0.213 \%$ change in GDP deflator in Table 1). Given the flexible exchange rate setting, the decrease in price level will transfer to a further depreciation of Singapore dollar ( $0.147 \%$ increase in exchange rate in scenario II compared $0.137 \%$ increase in scenario I). The cheaper Singapore dollar substantially stimulates exports and thus the output of export-oriented industries, e.g. the output in scenario II increases by $4.126 \%$ for food manufacture, $5.223 \%$ for oil manufacture, $1.951 \%$ for electronics, and $5.254 \%$ for IT sector. These sectors employ a large number of professionals, salesmen and plant workers, so the expansion of these sectors leads to a significant wage increase for these occupations. Since the wage of each occupation is the same across sectors, the wage increase for these three occupations will increase the production costs of non-export sectors and thus lead to an increase in the prices of their products. As a result, the demand for non-export goods falls, asse does the demand for workers in non-export sectors. The net effect of this is a decrease in 
wages of occupations other than professionals, salesmen and plant workers because wages for these three occupations are predominantly determined by the increase in demand for exports.

In scenario (IV), Clerks benefitted most from the tourism subsidy policy, enjoying a 1.32\% wage increase, but other unskilled occupations suffered from significant wage cuts. For skilled workers, Managers and Tradesmen enjoyed wage rises, but Professionals and Technicians experienced small wage decreases. These results are consistent with the tourism subsidy policy and the reality of the tourism industry in Singapore: all subsidies go to tourism sectors, which employ a large number of Clerks, significant number of managers and tradesmen, but only a small number of workers from other occupations.

\subsection{Sensitivity tests}

Many elasticity values are used in the model. We put them into different groups: export demand elasticities, product-transformation elasticities, and various substitution elasticities (that is Armington elasticities, occupational elasticities, and primary factor elasticities). We conducted the sensitivity tests by groups.

In normal sensitivity tests, we double and halve the values whichvalues that are used in the model application and compare the new simulation results with the baseline case. We used this conventional approach for most tests. For the tests on export demand elasticities, since we have assumed in the simulation that most exports are very elastic and have chosen relatively high values for them, we tested downwards movement of these elasticities. That is to halve and quarter the value used in model applications. The sensitivity tests were performed on a number of macroeconomic variables, but the changes in real GDP are the most important. Due to space limitations, we display in Figure 2 only the change in real GDP.

A glance at Figure 2 shows that the values used for exports demand elasticities were only slightly sensitive. The values for CET elasticities demonstrated marginal sensitivity (less than 5\% variation 
when its elasticity values in the model is doubled or halved). The modeling results were marginally sensitive to the values we used for Armington elasticity (between imported and local produced intermediate inputs) and to the value of occupation elasticity (between different occupation groups), and mildly sensitive to values of primary factor elasticity (between capital and labour). The mild sensitivity of primary factor elasticity value is a little worrying as it would not affect the general conclusions we obtained. Nevertheless, we should bear in mind that, when the values for this elasticity are higher, the simulated results could be greater.

Figure 2 Results of sensitivity tests - GDP outcomes

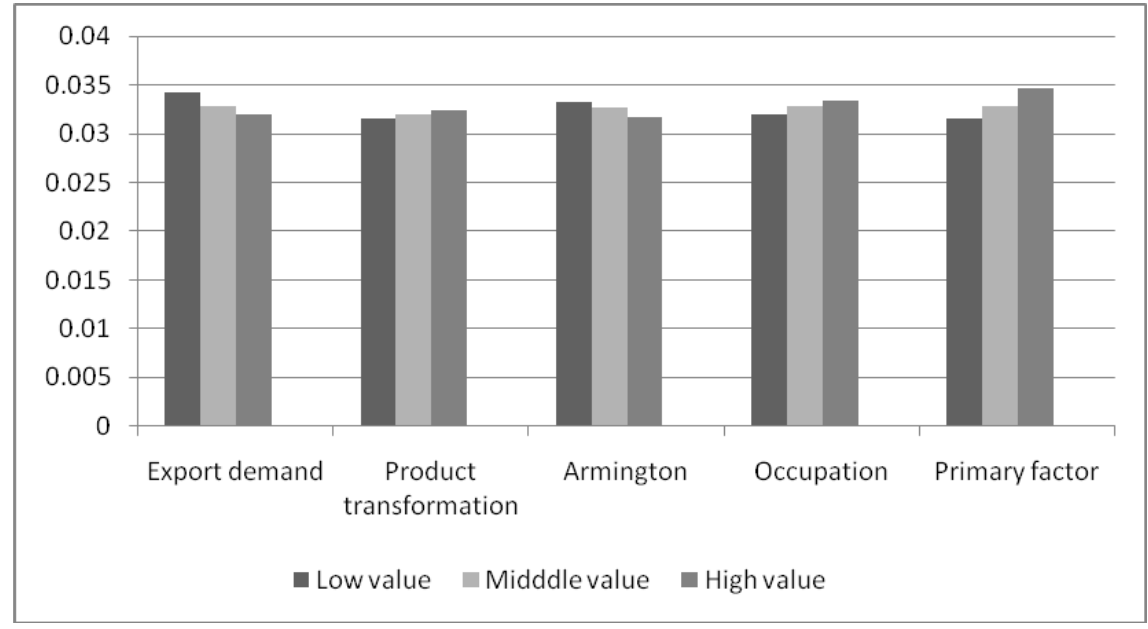

Source: based on authors’ simulation test results.

\section{Conclusions}

Based on the CGE model simulations, this paper has analysed the macro, sectoral and wage effects of the 2008 Global Financial Crisis and selected policy responses. Without a policy in position, the overall price level dropped slightly, but the prices of tourism goods and services decreased significantly and the price for investment goods increased noticeably. The depreciation of the Singapore dollar and the deterioration of terms of trade reduced real imports slightly and increased real exports significantly. Both GDP and factor cost index decreased noticeably, with a 
marginal increase in payment to capital and a significant decrease in payment to labour. As a result of the decrease in real GDP, total tax revenue decreased by about 19 billion dollars.

The results of policy responses show that the GST deduction policy was the most effective policy overall and the tourism--focused industrial subsidy policy was the least effective in terms of change in real GDP. At the sectoral level, the GST deduction policy seemed to benefit industries with high volume of output, the economy-wide subsidy policy may have brought more benefit to high production cost industries, and the tourism focused subsidy policy delivered significant positive change to the tourism industry. The policy implication of this study is that a comprehensive policy approach is needed to respond to an event like the GFC. It is desirable to establish a major policy to respond to an economy-wide problem while using a supplementary policy to counteract the drawbacks of the main policy. In the case of a negative tourism demand shock in Singapore, a GST reduction policy can be considered as the main policy response and a comparatively low tourism subsidy policy can be used to ease the pain of unemployment in the tourism sector.

\section{References}

Adams, P.=D., P. B. Dixon, P.B. and M. T. Rimmer, M.T.2002, The September 11 sshock to tTourism and the Australian eEconomy from 2001-02 to 2003-04.-Australian Bulletin of Labour, 27, pp. 24-257.

Blake, A. 2000, The eEconomic eEffects of țourism in Spain. Discussion Paper Series 2000/2, Christel DeHaan Tourism and Travel Research Institute, University of Nottingham [online; cited December 2014.] Available from URL:- http://www.nottingham.ac.uk/ttri/series.html-

Blake, A., M. Sinclair, M. and G. Sugiyarto,-G. 2003, Quantifying the itmpact of fFoot and

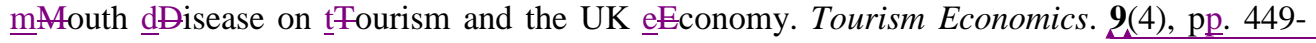
465.

Briassoulis, H. 1991, Methodological îfssues: Tourism îfnput-output âAnalysis. Annals of Tourism Research, 18, pp. $\div 435-449$.

Chan, V. 2011, The impact of the global financial crisis on the entertainment tourism industry: A financial engineering case study of Macao from 2007 to 2010.; Systems Engineering Procedia, 1: 323-329.

Chirathivat, S., and S. Mallikamas,, S., 2010, Thailand's economic performance and responses to the Global Crisis, a paper presented at the ACAES Conference "Asia After the Crisis"-, Doshisha University, 5-6 March, Kyoto.

Chon K, G. Li, S. G, Gin S, and Z.- Gao, Z. 2010, Recovery of tFourism dĐemand in Hong Kong from the Global Financial and Economic Crisis. Journal of China Tourism Research, 6 (3), pp. 259-278.
Formatted: Indent: Left: $0 \mathrm{~cm}$ Hanging: $0.63 \mathrm{~cm}$, No bullets or numbering

Formatted: Font: 12 pt, Font color: Auto

Formatted: Font: $12 \mathrm{pt}$, Not Italic, Font color: Auto

Formatted: Font: 12 pt, Font color: Auto

Formatted: Font: $12 \mathrm{pt}$, Italic, Font color: Auto

Formatted: Font: $12 \mathrm{pt}$, Font color: Auto

Formatted: Font: $12 \mathrm{pt}$, Bold, Font color: Auto

Formatted: Font: 12 pt, Font color: Auto

Formatted: Font: $12 \mathrm{pt}$

Formatted: Font: $12 \mathrm{pt}$, I talic

Formatted: Font: $12 \mathrm{pt}$

Formatted: Font: $12 \mathrm{pt}$

Formatted: Font: $12 \mathrm{pt}$

Formatted: Font: 12 pt, Font color: Auto

Formatted: Font: 12 pt, Bold, Font color: Auto

Formatted: Font: $12 \mathrm{pt}$, Font color: Auto

Formatted: Font: $12 \mathrm{pt}$

Formatted: Font: $12 \mathrm{pt}$, Bold

Formatted: Font: $12 \mathrm{pt}$

Formatted: Font: $12 \mathrm{pt}$, I talic

Formatted: Font: $12 \mathrm{pt}$

Formatted: Font: (Default) Times

New Roman, 12 pt

Formatted: Font: $12 \mathrm{pt}$

Formatted: Font: (Default) Times New Roman, 12 pt

Formatted: Font: $12 \mathrm{pt}$

Formatted: Font: (Default) Times New Roman, 12 pt

Formatted: Font: $12 \mathrm{pt}$

Formatted: Font: (Default) Times New Roman, 12 pt

Formatted: Font: $12 \mathrm{pt}$

Formatted: Font: (Default) Times New Roman, 12 pt

Formatted: Font: $12 \mathrm{pt}$

Formatted: Font: (Default) Times New Roman, 12 pt

Formatted: Font: $12 \mathrm{pt}$

Formatted

Formatted

Formatted 
Diamond, J. 1977, Tourism's rRole in eEconomic dĐevelopment: A c $\underline{\text { E }}$ Ease rRe-examined. Economic and Cultural Change, 25:539-553.

Euromonitor, 2007, Top 150 cGity dĐestinations: London l_eads the wWay, [online; cited December 2014.] Available from URL: http://www.euromonitor.com.

Heng, T. M. L. and Low, L. 1990, Economic ifmpact of țfourism in Singapore. Annals of Tourism Research, 17(2): 246-69.

Horridge. M. , 2000, ORANI-G: A gGeneral eEquilibrium mAodel of the Australian eEconomy.; Centre of Policy Studies/IMPACT Centre Working Papers, op-93, Monash University.

Johnson, R. 1999, Input-output $\underline{m} M$ Models with and without tThe $\underline{m}$ Multiplier eEffect, in Valuing Tourism: Methods and Techniques, Occasional Paper No. 28, Bureau of Tourism Research Canberra.

Khan, H., C. -Seng, C. and W. Cheong,W. 1990, Tourism mMultipliers eEffects on Singapore. Annals of Tourism Research, 17, pp. $\div 408-418$.

MTI (Ministry of Trade and Industry). 1960-2012. Singapore Year book.,-Singapore.

MTI (Ministry of Trade and Industry). 2008, 2013, Economic Survey of Singapore.; Singapore.

MTI (Ministry of Trade and Industry), 2009, MTI Revises Forecasts for 2009 GDP Growth [online; cited December 2014.] Available from URL: http://www.singstat.gov.sg/news/news/gdp4q2009.pdf.

Narayan, P. 2003, Economic iImpact of the 2003 South Pacific Games for Fiji, Economic Papers, 22(3): 60-73

Parikh, A. 1979, Forecasts of input-output matrices using the R.A.S. method - - The Rfeview of Eeconomics and Sstatistics, 61(3), pp. 477-481.

RNCOS. 2009, Opportunities in Singapore țourism ilndustry (2007-2009). [online; cited December 2014.] Available from URL: http:// www.rncos.com/report/IM504/htm.

Rodolfo, M., 2009, The Global Crisis and Philippine tFourism: Impact and pPolicy rResponsesresponses, ITB World Travel Trends report by IPK International _online; cited December 2014.] Available from URL:,-http:// www.ilo.org/wcmsp5/groups/public/--ed.../wcms 214576.pdf.

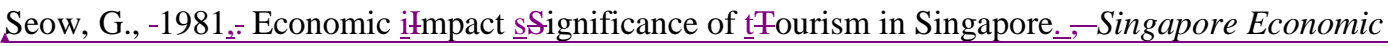
Review 26, pp. $\div 64-79$.

Shankaran, N., 2009, Malaysia and the global crisis: impact, response, rebalancing stragetiesstrategies, $A D B I$ Wworking Ppaper series, No. 148.

STB (Singapore Tourism Board) (STB). 2000-2009, Annual report on tourism statistics, various issues, 2011, [online; cited December 2014.] Available from URL: -http://www.stb.gov.sg.

STB (Singapore Tourism Board)_(STB), 2009, Tourism Factsheets, [online; cited December 2014.] Available from URL: http://www.stb.gov.sg,

Siriwardana, M. and D. Schulze,-D. 2000, Singapore and the Asian Economic Crisis: an aAAssessment of pPolicy rResponses, ASEAN Economic Bulletin. 17 $\div(3-)$, pp. 233-256

Stone, R. and \& A. Brown,-A. 1962, A Computable Model of Economic Growth. (A Programme for Growth), Volume 1 London, Chapman \& Hall.

Stone, R., D. G. Champernowne, D.G. and \& J. E. Meade,-J.E. 1942, The precision of national income estimates, Review of Economic Studies, 9, pp. 111-125.

\begin{tabular}{|l|}
\hline Formatted \\
\hline Formatted \\
\hline Formatted: Font: $12 \mathrm{pt}$ \\
\hline Formatted \\
\hline Formatted \\
\hline Formatted \\
\hline Formatted \\
\hline Formatted \\
\hline Formatted \\
\hline Formatted: Font: $12 \mathrm{pt}$, Font color: \\
\hline Formatted \\
\hline
\end{tabular}

